\section{Clinical Significance of Acquired Resistance}

It is important that the clinician should be familiar with the drugs to which resistance may be readily acquired, as, for reasons which are outlined below, such drugs should always be used in combination. In the chemotherapy of infections other than tuberculosis commonly used antibiotics may be classified as follows:

\begin{tabular}{l|l}
\multicolumn{2}{|c}{ Risk of Acquired Resistance } \\
\multicolumn{1}{c|}{ High Risk } & Low Risk \\
Streptomycin & Penicillin \\
Erythromycin & Tetracyclines \\
Novobiocin & Chloramphenicol \\
Lincomycin & Colistin \\
& Polymyxin B \\
& Gentamicin \\
& Cycloserine
\end{tabular}

Resistance is rapidly acquired to almost all antituberculosis drugs if used alone, with the possible exception of cycloserine.

Rapidly acquired drug resistance is of great clinical importance and always a potential danger in the individual patient if one of these drugs is used alone. In general, strains rendered resistant in this way do not easily revert to sensitivity, though this is said to be commoner with erythromycin than with other drugs. The mechanism may be illustrated by pulmonary tuberculosis treated with a single drug. In any large population of "isoniazid-sensitive" tubercle bacilli about one in a million is a naturally occurring resistant mutant (Fig. 6). Under satural conditions the proportion remains small probably because the resistant mutants are at a slight biological disadvantage compared with sensitive bacilli. If isoniazid is given alone the sensitive bacilli diminish in numbers and the isoniazid-resistant mutants are now at a biological advantage. If the population is large and the patient's defences are poor, the resistant mutants may increase and ultimately replace the sensitive population. These resistant bacilli usually persist for the rest of the patient's life, and may indeed infect other people.
On the other hand, if both streptomycin and isoniazid are given to the patient (Fig. 7), streptomycin affects not only the isoniazid-sensitive population but also the isoniazid-resistant mutants. There are also, of course, a small number of strepto-
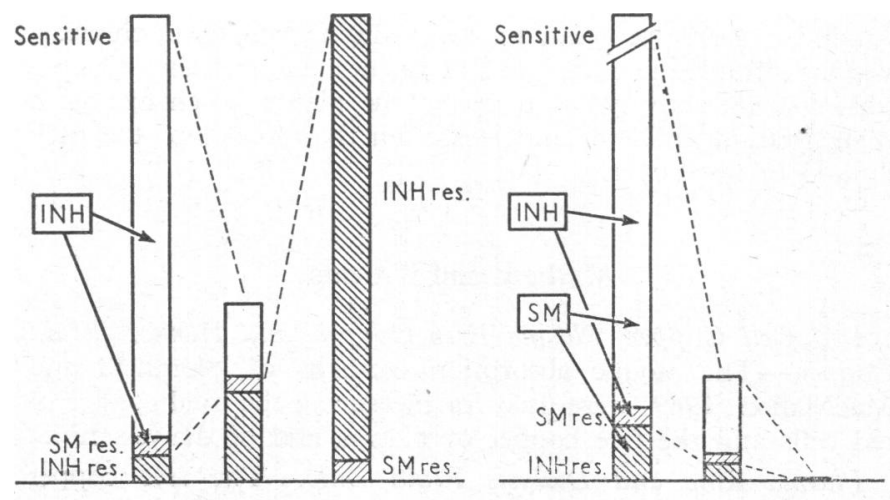

FIG. 6

FIG. 7

FIG. 6.-Emergence of isoniazid (INH) resistance with single-drug therapy. $S M=$ streptomycin. FIG. 7.-Preventing resistance by combined chemotherapy.

mycin-resistant mutants (about 1 in $10^{7}$ ), but these are inhibited by the isoniazid. In this way the emergence of resistant organisms is prevented. In clinical tuberculosis if a drug is given alone, resistant organisms may take from two weeks to two months to appear, but if streptomycin is used alone to treat pneumonia due to Klebsiella pneumoniae resistant organisms may emerge within a day or two. Therefore whenever one of these high-risk drugs is used to treat an infection it should always be used in combination with another drug to which the organisms are sensitive, and with which there is no crossresistance.

[The conclusion of this lecture, together with a list of references, will be published next week.]

\title{
Active Uptake of Copper and Zinc during Haemodialysis
}

\author{
JEANETTE BLOMFIELD,* M.sc., F.A.A.C.B. ; JEAN MCPHERSON, $\dagger$ M.B., B.s. ; C. R. P. GEORGE, $\dagger$ M.B., B.s.
}

Summary: The uptake of copper and zinc by patients $\checkmark$ undergoing regular haemodialysis has been assessed by measuring the dialysis fluid for copper and zinc concentration, and the blood entering and leaving the dialysis coil for red cell copper, plasma free copper, and plasma zinc levels during priming of the coil and subsequent haemodialysis, and by in-vitro studies.

Red cells avidly removed copper from dialysis fluid when mixed with saline during priming, but did not take up copper during the haemodialysis. At both these stages plasma actively took up both copper and zinc from dialysis fluid, even against a concentration gradient, so that loss of these metals from plasma to dialysis fluid did not occur.

In the dialysis systems investigated the sources of the copper in the dialysis fluid were the copper plumbing of the tap-water and the dialysis coil, and the major source of zinc was the zinc oxide of the adhesive plaster around the dialysis coil.

\section{Introduction}

Lyle (1967) demonstrated loss of copper from dialysis fluid during haemodialysis and sug; ested that uptake of copper by the patient may be contributing to the haemolytic anaemia of these patients.

We have investigated both copper and zinc during haemodialysis by measuring their concentrations in tap-water and dialysis fluid, in blood taken before entering the dialysing coil, and in blood returning to the patient from the coil after dialysis.

The aim was to determine whether copper and zinc are taken into the blood and whether this mechanism could lead to toxic amounts of these metals entering the blood. A further aim was to see whether the body could be depleted of these minerals by dialysing against low concentrations, in the same way that

* Senior Research Officer, Children's Medical Research Foundation, Royal Alexandra Hospital for Children, Camperdown, Sydney, Australia. † Registrar, Dialysis Unit and Medical Research Department, Sydney 
losses from blood can occur with low dialysis fluid concentrations of sodium, potassium, calcium, and magnesium.

The results presented in this paper show that blood concentrations of copper and zinc do not equilibrate with dialysis fluid levels, as is the tendency with the ions which are not bound by plasma proteins, such as sodium, potassium, chloride, and the ultrafilterable calcium and magnesium fractions. Copper and zinc are actively taken up by the plasma, even against a concentration gradient, and loss from the blood into the bath fluid does not occur.

\section{Methods and Patients}

Red Cell Copper, Plasma Free Copper, and Dialysis Fluid Copper.-The atomic absorption methods of Blomfield and MacMahon (1969) were used for measuring the total copper of red cells and the free copper of plasma and of dialysis fluid.

Plasma Zinc and Dialysis Fluid Zinc.-The free copper method of Blomfield and MacMahon (1969) was adapted to measure zinc. In this method zinc is chelated by ammonium pyrrolidine dithiocarbamate and extracted into $n$-butyl acetate.

Priming and Haemodialysis Sampling.-During the investigation of priming the dialysis coil was filled first with $500 \mathrm{ml}$. of saline and was followed by blood. Blood was collected before passing through the coil, and from one to three samples of blood with decreasing admixtures of saline were collected as the priming fluid left the coil. Simultaneous dialysis fluid samples were taken. Priming studies were carried out during 15 dialyses with blood direct from the patient, or the patient's blood which had been stored for two to three days in acidcitrate-dextrose, or normal donor blood in polyethylene bags with acid-citrate-dextrose, used freshly or stored for one or three days. Priming of machines was investigated at three different hospitals, in all of which the Travenol Kolff-coil was used. In addition, priming of the coil with saline and with albumin was investigated. In four patients blood and dialysis fluid sampling was repeated at intervals during the course of an eight-hour dialysis in which the 100 litres of bath fluid was changed at four hours.

In-vitro Studies.-In-vitro studies of the uptake of copper and zinc by plasma and red cells were carried out.

\section{Results}

Normal Ranges for Copper and Zinc.-For ease in interpreting the results the normal ranges for red cell copper, plasma free copper, and plasma zinc are given in Table I.

Table I.-Normal Ranges for Red Cell Copper, Plasma Free Copper (Blomfield and MacMahon, 1969), and Plasma Zinc Derived from the Blood of 50 Volunteer Blood Donors

$\begin{array}{llllr}\text { Red cell copper } & \ldots & \ldots & \ldots & \begin{array}{r}\text { Normal Range } \\ \text { Plasma free copper }\end{array} \\ \text { Plasma zinc } & \ldots & \ldots & \ldots & 5-15 \mu \mathrm{g} . / 100 \mathrm{ml} . \\ & . & \ldots & . & 60-110 \mu \mathrm{g} . / 100 \mathrm{ml} .\end{array}$

\section{Uptake of Copper and Zinc During Priming}

In the dialysis fluid the copper levels had a geometric mean of $15 \mu \mathrm{g} . / 100 \mathrm{ml}$. and the zinc levels had a geometric mean of $14 \mu \mathrm{g} . / 100 \mathrm{ml}$. (Fig. 1). The range of copper levels was from 9 to $26 \mu \mathrm{g} . / 100 \mathrm{ml}$. and of zinc from 0 to $630 \mu \mathrm{g}$. $/ 100 \mathrm{ml}$.

Haematocrits were performed on the samples collected after priming, and they were graded according to the amount of saline, sample 1 being mainly saline (haematocrit less than $5 \%$ ), sample 2 being about half saline, and sample 3 being mainly blood.

The red cell copper level geometric means increased dramatically from $79 \mu \mathrm{g}$. $/ 100 \mathrm{ml}$. before priming to $332 \mu \mathrm{g}$./ $100 \mathrm{ml}$. in sample 1 after priming (with a range of 75 to
$2,200 \mu \mathrm{g} . / 100 \mathrm{ml}$.), then diminished to $141 \mu \mathrm{g} . / 100 \mathrm{ml}$. in sample 2 , and returned to a nearly normal mean of $90 \mu \mathrm{g}$./ $100 \mathrm{ml}$. in sample 3 (Fig. 1).

The plasma free copper levels rose from a geometric mean of $9 \mu \mathrm{g} . / 100 \mathrm{ml}$. before priming, to mean levels of 15,26 , and $34 \mu \mathrm{g} . / 100 \mathrm{ml}$. after priming (Fig. 1).

The plasma zinc levels rose steadily after priming from a pre-priming geometric mean of $77 \mu \mathrm{g} . / 100 \mathrm{ml}$. to means of 125,215 , and $313 \mu \mathrm{g} . / 100 \mathrm{ml}$. after priming (Fig. 1).

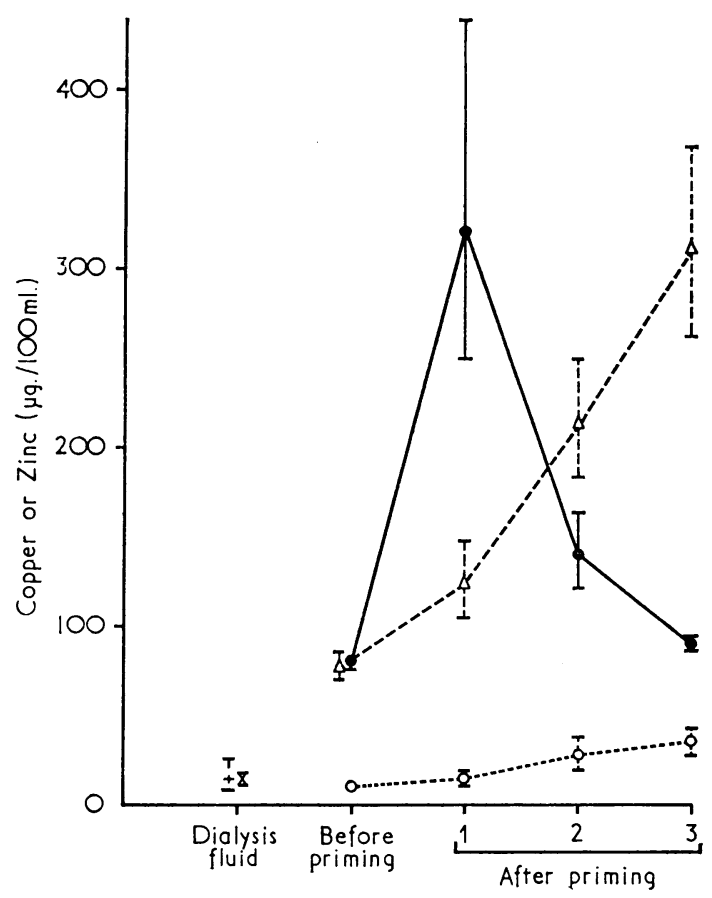

FIG. 1.-Uptake of copper by red cells and plasma and of zinc by plasma from dialysis fluid during priming of Kolffzinc by plasma from dialysis fluid during priming of Kolff1,2 , and 3 after priming are blood samples containing diminishing quantities of saline. The results are expressed as geometric means \pm standard errors. $\times$ Dialysis fluid copper. + Dialysis fluid zinc. $\longrightarrow$ Red cell copper. O -- - O Plasma free copper. $\triangle \cdots \triangle$ Plasma zinc.

\section{Uptake of Copper and Zinc During Haemodialysis}

During the course of an eight-hour dialysis there was no evidence of uptake of copper by the red cells of the patient's blood passing through the coil (mean arterial red cell copper $84.3 \mu \mathrm{g} . / 100 \mathrm{ml}$; ; mean venous return red cell copper $84.5 \mu \mathrm{g} . / 100 \mathrm{ml}$.), nor was there any increase in the red cell copper level in arterial blood during the course of the haemodialysis (predialysis arterial level $85 \mu \mathrm{g} . / 100 \mathrm{ml}$.; seven-hour arterial level $82 \mu \mathrm{g} . / 100 \mathrm{ml}$.). Both copper and zinc, however, were absorbed through the dialysis tubing into the plasma, the levels of both free copper and zinc in plasma after passing through the coil being about twice the levels of arterial plasma before entering the coil (Figs. 2 and 3 ). There was also some increase in arterial plasma free copper and zinc levels, particularly before the original bath fluid was replaced at four hours. When the levels of copper and zinc were lower in dialysis fluid than in plasma, metals did not pass out of the plasma into the dialysis fluid, but, on the contrary, they were actively taken up by the plasma despite the gradient (Figs. 2 and 3 ).

An assessment of the total uptake of copper and zinc during haemodialysis was made by multiplying the mean of the increase in plasma levels after passing through the coil by the estimated plasma flow rate of $100 \mathrm{ml} . / \mathrm{min}$. and by the dialysis time of seven hours. In the four patients assessed in this way the approximate uptake of copper was $0.8,1.3,2.9$, and $5.0 \mathrm{mg}$. and of zinc was $16.4,25 \cdot 2,16.4$, and $29.0 \mathrm{mg}$. In these four 
patients the mean dialysis fluid levels of copper were $8,12,15$, and $16 \mu \mathrm{g} . / 100 \mathrm{ml}$. and of zinc were $74,83,32$, and $44 \mu \mathrm{g}$./ $100 \mathrm{ml}$.

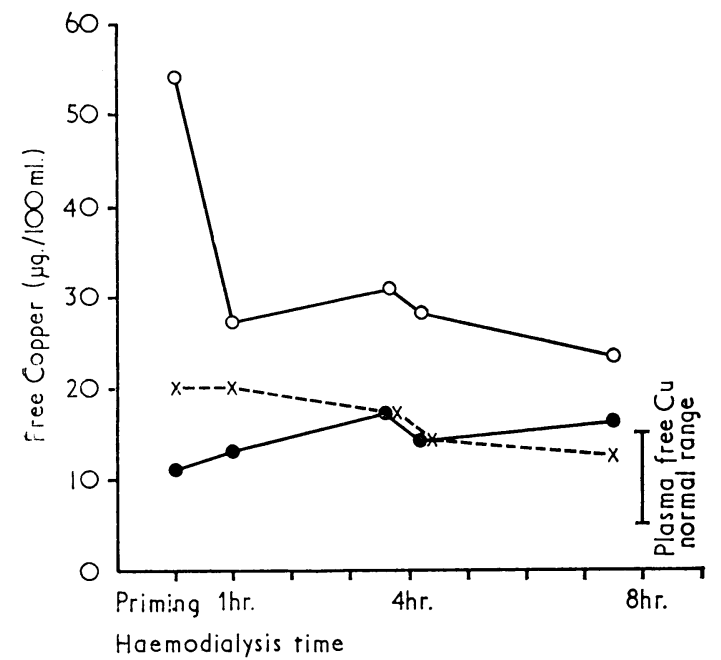

FIG. 2.-Uptake of copper by plasma from dialysis fluid during an eight-hour haemodialysis in a Kolff-type artificial kidney. The dialysis fluid was replaced at four hours. $\times \ldots \times$ Dialysis fluid copper. Plasma free copper, before passing through the coils. O-O Plasma free copper, after passing through the coils.

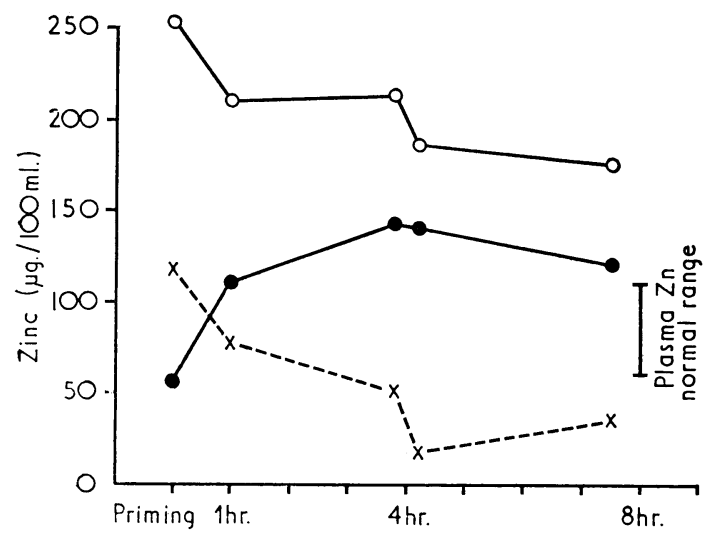

Haemodialysis time

FIG. 3.-Uptake of zinc by plasma from dialysis fluid during an eight-hour haemodialysis in a Kolff-type artificial kidney. The dialysis fluid was replaced at four hours. $x---x$ Dialysis fluid zinc. Plasma zinc, before passing through the coils. $\mathrm{O}-\mathrm{O}$ Plasma zinc, after passing through the coils.

\section{Priming by Saline and Albumin}

Priming the coil with saline resulted in an equilibrium of copper and zinc between dialysis fluid and saline, but when albumin was used for priming there was an active uptake, the concentrations in albumin rising by more than the original concentrations in the dialysis fluid (Table II).

TABLE II.-Priming of Artificial Kidney Dialysis Coil by Saline and Albumin, Showing Equilibrium of Saline with Dialysis Fluid Copper and Zinc and Active Uptake by Albumin of Copper and Zinc from the Dialysis Fluid

\begin{tabular}{|c|c|c|c|c|}
\hline & & & $\begin{array}{c}\text { Copper } \\
(\mu \mathrm{g} . / 100 \mathrm{ml} .)\end{array}$ & $\underset{(\mu \mathrm{g} . / 100 \mathrm{ml} .)}{\text { Zinc }}$ \\
\hline $\begin{array}{l}\text { Saline priming: } \\
\text { Dialysis fluid . . . } \\
\text { Saline before priming } \\
\text { Saline after priming }\end{array}$ & $\because$ & $\begin{array}{l}\cdots \\
\therefore\end{array}$ & $\begin{array}{r}12 \\
2 \\
7\end{array}$ & $\begin{array}{r}42 \\
7 \\
42\end{array}$ \\
\hline $\begin{array}{l}\text { Albumin priming: } \\
\text { Dialysis fluid } . \\
\text { Albumin before priming } \\
\text { Albumin after priming }\end{array}$ & $\because$ & $\begin{array}{l}\because \\
\because \\
\end{array}$ & $\begin{array}{r}23 \\
72 \\
179\end{array}$ & $\begin{array}{r}66 \\
38 \\
220\end{array}$ \\
\hline
\end{tabular}

\section{Age of Priming Blood and Uptake of Copper by Red Cells}

There were no obvious differences in uptake of copper by red cells during priming between blood direct from the patient's artery or blood stored before use in plastic bags containing acid-citrate-dextrose for a few hours, one day, or three days. The red cell copper uptake appeared to be mainly influenced by the amount of saline, the time in the coil, and the level of copper in the dialysis fluid.

\section{Source of Copper and Zinc in Dialysis Fluid}

One source of copper contamination appeared to be in the tap-water, and, as recommended by Lyle (1967), running the tap-water for five minutes reduced the copper content from 25 to $9 \mu \mathrm{g} . / 100 \mathrm{ml}$. The zinc content also diminished, from 19 to $2 \mu \mathrm{g} . / 100 \mathrm{ml}$.

There was also some source of copper contamination within the machine, probably in the dialysis coil. Recirculation of dialysis fluid for an hour before the coil was inserted did not result in any rise in the copper level, but after the coil was inserted a further hour of recirculation resulted in an increase of the copper level by $5 \mu \mathrm{g} . / 100 \mathrm{ml}$.

Little or no contamination by copper and zinc was found from the dialysis salt concentrates, the syringes and needles, or collection tubes, or in most of the injections used. Both heparin and protamine sulphate contained considerable quantities of copper and zinc, but, with the small volume used, dilution would have negated these quantities.

The source of the zinc contamination was eventually traced to the zinc oxide of the adhesive plaster used to keep the coil from unwinding. Sixteen feet $(4.9 \mathrm{~m}$.) of 1 in. $(2.5 \mathrm{~cm}$.) and $7 \mathrm{ft} .\left(2 \cdot 1 \mathrm{~m}\right.$.) of $\frac{1}{2}$-in. $(1 \cdot 3-\mathrm{cm}$.) adhesive plaster are used to stabilize the coil in the tank. A 5 -in. $(12 \cdot 5-\mathrm{cm}$.) strip of this plaster immersed for 30 minutes in $5 \mathrm{ml}$. of $0.1 \%$ ammonium pyrrolidine dithiocarbamate resulted in a zinc level of $1,200 \mu \mathrm{g}$./ $100 \mathrm{ml}$.

In one haemodialysis the major portion of the adhesive tape, which is round the outside of the coil, was replaced by clear vinyl tape, leaving only a small amount attaching the tubing at the centre of the coil. This procedure resulted in greatly decreased levels of zinc in the dialysis fluid, no increase in the arterial plasma zinc levels after one hour, and a decrease of the uptake of zinc by plasma at one hour from $101 \mu \mathrm{g} . / 100 \mathrm{ml}$. when the adhesive tape was used to $14 \mu \mathrm{g} . / 100 \mathrm{ml}$. (Table III).

TABLE III.-Comparison of Zinc Levels During Haemodialysis, When
the Dialysis Coil was Used as Supplied, and When the Outer
Adhesive Tape was Replaced by Vinyl Tape, Leaving Only a Small
Quantity of Zinc Oxide at the Centre of the Coil

\section{In-vitro Studies of Copper and Zinc Uptake}

In-vitro studies have confirmed the priming and haemodialysis studies of patients. Red cells suspended in plasma containing copper took up little copper, but when suspended in saline the copper uptake by the red cells was high (Table IV). Glucose added to the saline in physiological concentration $(100 \mathrm{mg} . / 100 \mathrm{ml}$.) did not appear to protect the red cells from copper uptake, but albumin ( $5 \mathrm{~g} . / 100 \mathrm{ml}$.) afforded partial protection (Table IV). 
With in-vitro dialysis there was active uptake of copper and zinc when the dialysis fluid contained these metals, but there was no loss from the plasma to the dialysis fluid when the dialysis fluid was free of copper or zinc (Table V).

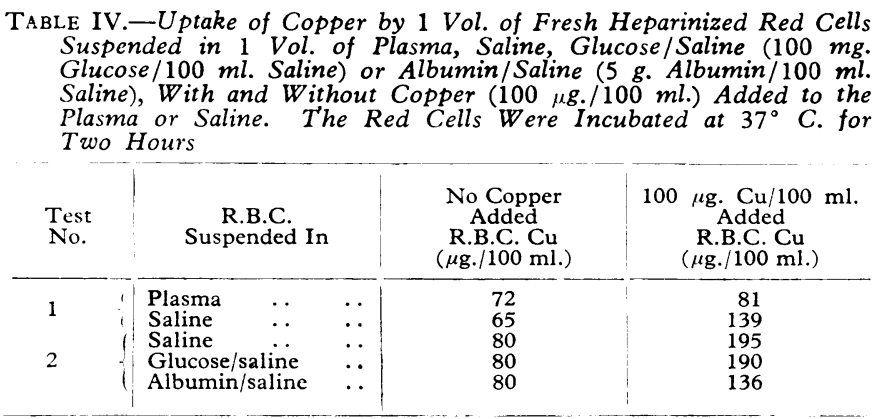

TABLE V.-In-vitro Dialysis of 1 Vol. of Fresh Heparinized Plasma Against 100 Vols. of Dialysis Fluid, With and Without Copper or Zinc Added. Dialysis Was Carried Out in a Shaker Incubator at $37^{\circ}$ C. for 10 Minutes

\begin{tabular}{|c|c|c|c|c|}
\hline & & $\begin{array}{l}\text { Dialysis Fluid } \\
\text { Cu or } \mathrm{Zn} \text { Content }\end{array}$ & $\begin{array}{c}\text { Plasma Free Cu } \\
(\mu \mathrm{g} . / 100 \mathrm{ml} .)\end{array}$ & $\begin{array}{c}\text { Plasma Zinc } \\
(\mu \mathrm{g} . / 100 \mathrm{ml} .)\end{array}$ \\
\hline $\begin{array}{l}\text { Predialysis } \\
\text { After dialysis } \\
\text { After dialys; } \\
\text { After dialysis } \\
\text { After dialysis } \\
\text { After dialysis }\end{array}$ & $\theta^{\circ}$ & $\begin{array}{l}\text { No Cu or } \mathrm{Zn} \\
\text { Cu } 10 \mu \mathrm{g} . / 100 \mathrm{ml} \text {. } \\
\text { Cu } 100 \mu \mathrm{g} . / 100 \mathrm{ml} \text {. } \\
\mathrm{Zn} 10 \mu \mathrm{g} . / 100 \mathrm{ml} \text {. } \\
\mathrm{Zn} 100 \mu \mathrm{g} . / 100 \mathrm{ml} \text {. }\end{array}$ & $\begin{array}{r}7 \\
9 \\
25 \\
145 \\
12 \\
12\end{array}$ & $\begin{array}{r}80 \\
90 \\
84 \\
84 \\
107 \\
290\end{array}$ \\
\hline
\end{tabular}

\section{Discussion}

A reassuring finding from these studies is that copper and zinc deficiency will not result direct from haemodialysis since these metals are too firmly bound by plasma proteins to be removed from the blood, even when they are in low concentration or absent from the dialysis fluid. These findings confirm in-vitro studies with copper by Gubler, Lahey, Cartwright, and Wintrobe (1953) and with zinc by Berfenstam (1952), who found that copper and zinc could not be dialysed from plasma at physiological $\mathrm{pH}$. However, Berfenstam found that plasma or $4 \%$ albumin in saline will bind zinc at a concentration of $1,000 \mu \mathrm{g} . / 100 \mathrm{ml}$. in an undialysable form. We have therefore only to consider the question of uptake and the possibility of copper or zinc toxicity.

Although high red cell copper levels are found in the first few millilitres of blood mixed with saline during priming, the red cell copper levels return to normal when the saline has been flushed from the coils. Thus direct uptake of copper by red cells likely to lead to clinically significant haemolysis was not found.

Since plasma actively binds copper and zinc from solutions of crystallinity, nearly the total amount of these metals in the dialysis fluid is available for assimilation. The amount of copper or zinc absorbed cannot be determined by deducting the amount in the dialysis fluid before it is discarded from the amount initially present, since these two metals are continually dissolving from the coil and its adhesive tape during circulation of the dialysis fluid. As an alternative the concentration difference in the blood issuing from and entering into the coil can be multiplied by the amount of blood passing through the coil to give an estimate of total uptake.

Copper and zinc are rapidly removed from the blood stream by the liver, and with high copper ingestion the red cell copper levels also rise ( Gubler et al., 1953 ; Chuttani, Gupta, Gulati, and Gupta, 1965). The major excretory route of these metals is along the gastrointestinal tract, copper being in particularly high concentration in the bile and zinc in pancreatic juice. The normal urinary excretion of copper is only $4-30 \mu \mathrm{g} . /$ day (Adelstein and Vallee, 1962) and of zinc is about 320-560 $\mu \mathrm{g} . /$ day (Vallee, 1962), so that impaired kidney function will not greatly affect excretion. These storage and excretory patterns make measurement of retention difficult and would necessitate full balance studies or determination of concentration in liver biopsy specimens.

Copper is a relatively toxic metal, and acute poisoning results in liver necrosis and in intravascular haemolysis which occurs about two days after ingestion of the copper. Fairbanks (1967), studying the in-vitro effects of copper sulphate on red cells, showed that the copper inhibits glucose-6-phosphate dehydrogenase, inhibits glycolysis in red cells, accelerates oxidation of nicotinamide adenine dinucleotide, denatures haemoglobin, and oxidizes glutathione, and thought that each of these effects may contribute towards red cell haemolysis. The inherited disorder of copper metabolism, Wilson's disease, in which free copper accumulates in liver and brain and in which plasma free copper levels are increased, leads over a period of many years to liver cirrhosis and neurological symptoms. It is sometimes associated with acute haemolytic episodes during one of which a high red cell copper level of $400 \mu \mathrm{g} . / 100 \mathrm{ml}$. has been reported (McIntyre, Clink, Levi, Cumings, and Sherlock, 1967). In repeated haemodialyses with high dialysis fluid copper levels it is likely that accumulation of copper in the liver would occur and haemolysis might result.

Zinc is not regarded as being particularly toxic. A high oral dose results in vomiting and diarrhoea, the emetic dose being 225-450 mg. (Van Reen, 1966). Zinc toxicity appears to be mainly related to its antagonistic effect on other minerals, and a high intake in animals leads to secondary deficiencies of copper, iron, and calcium, with resultant anaemia and osteoporosis (Van Reen, 1966 ; Vallee, 1962 ; Underwood, 1962). Possibly a high zinc uptake during haemodialysis would help to protect against copper toxicity.

Maher, Freeman, Schmitt, and Schreiner (1965) demonstrated adherence to Cellophane dialysis membranes of radioactive copper and zinc in tap-water and subsequent elution by whole blood. This affinity of the membranes for copper and zinc may contribute towards the high levels of these metals in the first samples of blood passing through the dialysis coil after the saline priming.

The amount of copper and zinc contamination will undoubtedly be greater if the $p \mathrm{H}$ of the tap-water or dialysis fluid is low. Paine (1968) reported that a farmhouse water supply coming from a spring via copper pipes and having a $\mathrm{pH}$ of 5.7 to 6.2 had a copper level of $760 \mu \mathrm{g}$. $/ 100 \mathrm{ml}$. at the first draw and $410 \mu \mathrm{g} . / 100 \mathrm{ml}$. at the second draw. A current survey of dialysis fluids in renal units around Australia has shown occasional copper levels in the region of 50 to $100 \mu \mathrm{g}$./ $100 \mathrm{ml}$. in both tap-water and dialysis fluids (Blomfield and Wilkinson, unpublished data). With a tap-water level of $100 \mu \mathrm{g} . / 100 \mathrm{ml}$. the daily oral intake of copper from this source is unlikely to exceed $5 \mathrm{mg}$., but haemodialysis against 240 litres of dialysis fluid with this copper level would subject the patient to a potential copper uptake of $240 \mathrm{mg}$. The average daily dietary intake of copper is 2 to $3 \mathrm{mg}$./day (Underwood, 1962).

The suggested procedure of Lyle (1967) of flushing taps before use should diminish the possibility of copper contamination from tap-water, but this procedure would not necessarily be effective in a large hospital complex with extensive copper plumbing. A further possible copper source is the copper heatexchanger in use with some types of artificial kidney machines.

Replacement of the adhesive tape on the dialysis coils should eliminate one source of zinc contamination, but the possibility remains of zinc being derived from galvanized piping or rubber tubing.

Note.-The manufacturers of the coils and machine, Travenol Laboratories, Morton Grove, Chicago, have indicated that they are changing from a copper to a stainless-steel sleeve in the pump used in the Travenol artificial kidney machine. Further, they are investigating several types of adhesive tape, and will be changing the type of tape used around the disposable coils. 
We wish to acknowledge the guidance and encouragement given by Dr. J. H. Stewart, of Sydney Hospital, Sydney. We are grateful for the assistance of Dr. D. Tiller, of Royal Prince Altred Hospital, Sydney, and of Dr. D. Jereny, of Prince Henry Hospital, Sydney, and for the willing co-operation of Sister C. O'Connor and othei members of the nursing staffs of the dialysis units.

REFERENCES

Adelstein, S. J., and Vallee, B. (1962). In Mineral Metabolism, edited by C. L. Comar and F. Bronner, vol. 2, part B, p. 371. New York and London, Academic Press.

Berfenstam, R. (1952). Acta pacaiaticica Uppuala, Suppl. No. 87 Blomfield, J., and MacMahon, R. A. (1969). Fournal of Clinical Pathology. In press.
Chuttan, H. K., Gupta, P. S., Gulati, S., and Gupta, D. N. (1965) Ainluican fouiral of Medicine, 39, 849

Firbanks, $V . F$ (1957) dichives of Internal Medicine, 120, 428

Ganks, E. Cartiwright, G. E., and Wintrobe, M. M (1953). Founal of Clinical Investigation, 32, +05.

Lyle, W. H. (1967). New England Fouinal of Medicine, 276, 1209

McIntyre, N., Clink, H. M., Levi, A. J., Cumings, J. N., and Sherlock S. (1967). New England fournal of Medicine, 276, 439.

Maher, J. F., Freeman, R. B., Schmitt, G., and Schreiner, G. E. (1965) Transactions of the American Society for Artificial Internal Organs, $11,104$.

Pain - C. H (1968). Laniet, 2, 520

Underwood, E. J. (1962). Trace Elements in Human and Animal Nutri. tion, 2nd ed. New York and London, Academic Press.

Vallee, B. L. (1962). In Mincial Metabolism, edited by C. L. Coma and F. Bronner, vol. 2, part B, p. 443. New York and London, Acadenic Press

Van Reen, R. (1966). In Zinc Metabolism, edited by A. S. Prasad, p. 411. Springfield, Illinois, Thomas.

\title{
Controlled Trial Comparing Effect of Two and Six Weeks' Treatment in Reeurrent Urinary Tract Insection
}

\author{
PRISCILLA KINCAID-SMITH,* M.D., M.R.C.P., F.R.A.C.P. ; KENNETH F. FAIRLEY, $†$ M.D., M.R.C.P., F.R.A.C.P. \\ With the Technical Assistance of Pamela Habesberger, B. SC., and Christine Gales
}

\begin{abstract}
Cummary : Patients with recurrent urinary tract infection were allocated at random to two weeks' or six weeks' treatment with an appropriate antibacterial drug. There was no difference in the results achieved by the two different periods of treatment as judged by the presence of infection in the urine one week and six weeks after treatment was stopped.

The urine was clear of infection in a higher percentage of patients following a course of nitrofurantoin than following a course of ampicillin, but the difference was not significant.
\end{abstract}

\section{Introduction}

Although long courses of treatment are widely used in urinary tract infection (Örsten et al., 1962 ; Campanacci et al., 1963; Murdoch et al., 1966 ; Seneca and Zinsser, 1966 ; Bengtsson et al., 1967) there have been very few controlled studies to determine the optimum duration of a course of treatment. The present study compares the effect of six weeks' treatment with that of two weeks' treatment in eradicating an episode of urinary tract infection. Patients with recurrent urinary tract infection were studied because therapeutic difficulties are most likely to arise in this group of patients.

\section{Selection of Patients}

A total of 142 females and 4 males aged 12-52 who had had more than one bacteriologically proved episode of urinary tract infection in the previous year were included in the study. For the purpose of inclusion a bacterial count of $>100,000$ organisms per ml. in a midstream urine specimen was accepted

\footnotetext{
* First Assistant in Medicine, University of Mclbourne Department of Medicine, the Royal Melbourne Hospital, Melbourne.

t Honorary Outpatient Physician, the Royal Melbourne Hospital, Melbourne.
}

as evidence of infection. Fifty-two patients were referred from medical wards and the remainder were referred as outpatients to a special clinic for recurrent urinary tract infection. Fortyfour patients had some radiological abnormality in the intravenous pyelogram, such as a small calculus, papillary necrosis, or chronic pyelonephritis, but patients with large calculi and obstructive lesions were excluded. With random allocation to treatment groups, patients showing radiographic abnormalities were equally distributed in the two groups ( 21 in one group and 23 in the other).

\section{Method of Study}

A total of 210 episodes of infection were studied in 146 patients. Thirty-one patients were treated twice and 11 patients three times. Patients were allocated at random to two or six weeks' treatment on the basis of the last digit of their hospital number. If admitted for a second or third course of treatment they were allocated alternately to two or six weeks' treatment. Midstream urine specimens were collected with care with a tampon in the vagina and were examined at once. The infecting organisms in the specimen taken before treatment are shown in Table I. Bacterial counts were performed on the specimens collected before treatment, on the second and third day of treatment, and one week and six weeks after stopping treatment. Although we required a bacterial count above 100,000 per $\mathrm{ml}$. before including a patient in this study, we accepted counts of over 10,000 per ml. as evidence of infection while on treatment or after cessation of treatment. We have established by needle aspiration of the bladder that 10,000 organisms per $\mathrm{ml}$. is a more accurate dividing line between infection and contamination when specimens are collected as described above and examined at once in our laboratory (Kincaid-Smith and Fairley, 1967).

In 148 episodes of infection ampicillin $500 \mathrm{mg}$. six-hourly or nitrofurantoin $100 \mathrm{mg}$. six-hourly was given. When the 